\title{
23 \\ The Industrial Relations Policy and Penalty
}

\section{David Peetz}

This chapter examines the role of industrial relations (IR) in the 2016 election, one that featured campaigns by and about (that is, against) trade unions. I commence with a brief history of industrial relations in Australian elections over several decades, including the 2007 'Your Rights at Work' (YRAW) campaign. I then discuss the parties' positioning on IR in the lead-up to the election over 2013-15, including two major inquiry reports. This is followed by the role played by key IR issues in the double dissolution, and the subsequent 2016 campaign-union misbehaviour, penalty rates and the Country Fire Authority (CFA) dispute-including a discussion of the union campaign against the government, with an assessment of its effectiveness and what might be seen as the industrial relations 'penalty' during the campaign.

\section{A brief history of industrial relations in Australian elections}

With unions being formally tied to the Australian Labor Party (ALP), conservative parties have long sought to discredit unions as a means to discredit the ALP. Indeed, the conflict between capital and labour is the core conflict within capitalism, so it should not surprise that it is also central to political conflict in Australia. Hence, IR is an area of strong 
ideological conviction for Coalition members-it is the issue on which surveys show the greatest difference between Coalition and Labor Party candidates (Taft 1998). It has featured prominently, one way or another, in many elections. Through the 1950s and 1960s, communist influence in the Labor Party, via unions, was a major issue pushed by the Liberal Party. In the 1974 and 1975 elections, the unions' role in 'wages explosions' were part of the strong economic critique of the then Labor government. In announcing the early 1983 election, prime minister Malcolm Fraser justified it by reference to the oil unions' refusal to accede to his government's wage freeze, though little was heard of that issue again. Instead, the ALP's 'Accord' with the union movement, in which wage restraint would be exchanged for improvements in the 'social wage' (public expenditures that affect living standards, such as health, education, housing, public transport and family payments), aided the economic credibility of the Labor opposition. Over the next decade, that Accord's role in economic management helped keep Labor in government. In the 1993 election, the conservative opposition promised radical changes in taxation (Fightback!), health and industrial relations (Jobsback!) in the context of a deeply unpopular recession. While Fightback! received most publicity, the conservative Victorian government's radical IR reforms gave salience to Labor's campaign against Jobsback!, and Labor's seat gains in Victoria offset its losses elsewhere. The Coalition's IR policy after that was much less radical. The 1998 election provided a model for two decades later when, prior to it, prime minister John Howard promised (accompanied by a large, publicly funded advertising campaign) to introduce a goods and services tax (GST), despite having promised in 1995 to 'never ever' do that. While losing the two-party preferred vote, with the assistance of the 'sophomore surge' (Brent 2010, 2014), the government was re-elected and the GST introduced. Nonetheless, in the context of a minority position in the Senate, the Coalition remained cautious on IR policy until unexpectedly winning a Senate majority in 2004.

Treating IR reform as 'an article of faith' drew Howard into overreaching in IR legislation less than a year later with the WorkChoices legislative agenda (Hudson 2005). Ignoring the 1998 election model, no mention was made of it before the 2004 election. Howard later said that voters should have been aware of it as their intention to overhaul the workplace 'has been very well known for a long period of time' (Coorey 2005). The main way in which WorkChoices affected workers' pay was by allowing employers to reduce penalty rates, overtime pay and shift allowances below the award safety net (Peetz 2007). Unions mobilised 
an extensive opposition campaign, Your Rights at Work (YRAW), in the media and through direct communication with members (Muir and Peetz 2010). Industrial relations became, for the first and only time since the Australian Election Study (AES) started asking in 1996, the most important election issue (McAllister and Cameron 2014). An antiunion—and anti-ALP — campaign by employer organisations, featuring images of union 'thugs' (using actors convicted of drug offences), was of little effect (Roberts 2010; Koutsoukis, Switzer and Gough 2007), nor was an expensive taxpayer-funded government campaign (Bachelard 2007). WorkChoices was widely seen as costing the Coalition the 2007 election (Crowe 2007; Maley 2007; Morris 2007)—an assessment endorsed by statistical analysis (Spies-Butcher and Wilson 2008).

In the light of these events, the Coalition in the 2010 and 2013 elections attempted to distance itself from its WorkChoices policy. Tony Abbott said when he became leader of the opposition, 'the phrase WorkChoices is dead. No one will ever mention it ever again' (Uhlmann 2009). He famously extended the metaphor to say WorkChoices was 'dead, buried and cremated' (Curtis 2010). Unions campaigned on the issue and reused the term WorkChoices, but it received less traction as time passed. Whereas the ALP had been the preferred party on industrial relations for 53 per cent of voters in 2007, compared to 32 per cent who preferred the Coalition's policies, by 2010 voters preferred the ALP by only 36 to 27 per cent and, in 2013, voters preferred the ALP by only one percentage point (McAllister and Cameron 2014). Unfortunately, the question was not asked in the 2016 AES (Cameron and McAllister 2016).

The strategy on IR in 2013 therefore appeared to be to follow the 1998 GST election model—something ignored with WorkChoices itselfwhich meant the following: being relatively silent about IR in the lead-up to the 2013 election; gaining victory in 2013 and, with it, a number of seats that would benefit from a 'sophomore surge' in 2016; announcing a major IR policy in the lead-up to the 2016 election; and winning the 2016 election with a mandate for major IR change thereafter. Hence, Coalition candidates, especially in Sydney, repeatedly declined interviews and public appearances, perhaps to avoid a repetition of the 2011 comment by Liberal MP John Alexander that penalty rates for working nights, weekends or overtime 'cannot be a good thing' (AAP 2011; Saulwick et al. 2013). Abbott explicitly likened his IR strategy to the Howard strategy on the GST when he was asked about the two, and said, 'I have no plans' to make major changes to workplace laws, 'but if there is to be any change far off into the future, obviously there should 
be a mandate for it' (O'Brien 2013). There were some minor glitches. One Coalition candidate for the 2013 election said that IR policies would only be put 'on the table after the election' (Australian Broadcasting Corporation (ABC) 2013). Senior Liberals were reportedly 'aghast' that Senator Eric Abetz had been 'freelancing' on IR when he made comments about limits on wage increases, contrary to the 'agreed strategy of keeping industrial relations off the front pages of newspapers during the campaign' (Kenny and Lucas 2013). When, in the second 2013 election debate, Kevin Rudd claimed that Tony Abbott had previously said the Howard government's industrial reforms were its 'finest achievements', Abbott dismissed this with 'I'd like to see the quote'. He could have found it in Hansard, where he had begun a speech 'by reminding members that workplace reform was one of the greatest achievements of the Howard government' (Abbott 2009). Not one of these mishaps was fatal to the 2013 election campaign.

\section{Positioning on industrial relations over 2013-15}

A major policy announcement on IR for 2016 would require a persuasive justification, in light of the planned silence in 2013, and the Coalition laid the groundwork for this with two major inquiries: the Productivity Commission, a market liberal government agency, was asked to report on the workplace relations framework; and conservative former jurist Dyson Heydon was hired to lead a royal commission into corruption and governance in trade unions. The former was promised in May 2013, four months before the 2013 election (Liberal Party of Australia and National Party 2013), and the latter was announced several months after it. Both inquiries could serve a concrete and important purpose-to provide 'thirdparty endorsement' for the policies the Coalition preferred to enact. The other requirement for a 2016 policy package was that it would need to be as effective as WorkChoices, but much more attractive. So it would need to place less emphasis than in 1996-2006 on directly reducing employee entitlements, and instead rely on directly attacking trade unions, whose power ultimately enabled employees to protect and boost their pay and conditions. This idea would build on the belief that voters had little faith in the honesty of the union leaders (Roy Morgan Research 2014), but perhaps underplayed the popular acceptance of unions' role in society (Peetz 2002, 2010). 
By 2014, many Coalition politicians still held strong views on IR and came to believe that WorkChoices had been 'neutralised' as an issue (Massola 2014). In 2015, as prime minister, Abbott was unable to resist advocating unspecified changes to penalty rates as he had trouble finding alcohol on religious holidays (Special Broadcasting Service (SBS) 2015; Taylor 2015). Nonetheless, political considerations had dictated that, if it won a majority in the House of Representatives, but not control of the Senate, a new Coalition government could not reintroduce WorkChoices in the same form as previously. And already it was having second thoughts about IR, exemplified by the frustrations of Liberal Senator Zed Seselja who called on the government to have the 'courage' to argue a cut in weekend penalty rates for hospitality and retail workers, in support of a Productivity Commission recommendation along those lines (AAP 2015).

What prompted these second thoughts was the failure of opinion polls to live up to expectations, undermining the earlier political strategy. Instead of enjoying a long 'honeymoon' period in the polls, as Howard and other new governments had experienced — a precondition for advancing a radical policy before its first re-election campaign - the new Abbott government soon found itself trailing (see e.g. Bowe 2015). There were several reasons, but one was the outcomes of promises made before the 2013 election yet broken, many in the 2014 Budget (in health, education, $\mathrm{ABC}$ funding and other areas), which greatly reduced trust in the government (ABC 2014; Hartcher 2014; Sydney Morning Herald 2014). The government could not guarantee re-election even with its existing policies, let alone with the addition of radical IR changes (Fisher 2014).

The Employment Minister retained his enthusiasm for doing something. In a speech appropriately titled 'Industrial relations after the 30 years war', Senator Eric Abetz (2014) made the controversial and widely reported claim that "we risk seeing something akin to the "wages explosions" of the pre-Accord era, when unsustainable wage growth simply pushed thousands of Australians out of work'. In other circumstances, strange talk of a wage explosion might have been excused as a rush of blood to the head. However, this was no off-the-cuff remark; it was the centrepiece of a carefully scripted speech. Indeed, there was nothing new about unsubstantiated talk of wages explosions; News Corp papers had run numerous stories and regularly editorialised on a forthcoming wages breakout that never materialised (Australian 2010a, 2010b, 2011a, 2011b, 2011c; McCrann 2008). By the middle of the decade, wages growth was falling to 'record' lows (Janda 2016). 
As it was, even those legislative changes to industrial relations that the government attempted to introduce were mostly blocked in the Senate. One was a proposal to make it easier for employers to avoid prosecution for individual flexibility arrangements (a pseudo-substitute for Australian Workplace Agreements, introduced in Labor's Fair Work Act 2009) that were substandard. It would also have allowed non-monetary benefits to be taken into account in assessing whether workers were better off, leading to claims that employees could be paid in pizza (Price 2014). Another bill-to block that wages explosion-would have given the Fair Work Commission (FWC) a role in determining whether a claim was 'manifestly excessive' or whether it would 'have a significant adverse effect on productivity' before allowing a protected action ballot to occur (Fair Work Amendment (Bargaining Processes) Bill 2014). This proposal would have essentially returned wage bargaining to a situation like that existing over two decades earlier. The Coalition, which for many years sought to 'prevent unwarranted interference by third parties in agreement making' (Abbott 2002), proposed in government to promote such interference.

By September 2015, Abbott had become so unpopular that he was deposed by his party. The change of prime minister had an impact on IR, but action on the issue remained constrained by the opinion polls. While Abbott was renowned for an extremely conservative social philosophy, he was one of the few ministers later asserted to be hesitant about the direction of WorkChoices (Gawenda 2014). Turnbull showed little evidence of his being less enthusiastic than Abbott about lowering pay or conditions; he described the reduction of penalty rates as inevitable (Bourke 2015).

Abbott's close supporter, Abetz, lost his position in the ministry, having achieved very little as minister in charge of industrial relations. Abetz was replaced by Michaelia Cash. Her approach was two-fold: she focused on demonising trade unions, through highlighting some preliminary findings of the Heydon trade union royal commission; and she talked up the importance of the Senate passing legislation re-establishing the Australian Building and Construction Commission (ABCC). These lines of argument became almost indistinguishable, and soon Cash linked the ABCC legislation to the Heydon inquiry (Doran and Dziedzic 2016). 
Labor's spokesperson on IR issues in the lead-up to the election was Brendan O'Connor. He had held various ministerial responsibilities during the Gillard-Rudd years, was in Cabinet for Labor's last 18 months in government and had been Labor's employment and workplace relations spokesperson from when Bill Shorten had become leader. He had a background as a union official, but only spent a few weeks as employment minister in the final Rudd ministry. He did not have a high profile, but the key thing for a Labor opposition spokesperson in this area to do was not to stuff up. O'Connor was expert at that. The temptation for Labor (and the unions) had been to label each snippet of insight into government policy as 'WorkChoices revisited'. Neither the Coalition's 2013 policy, nor the recommendations of the Productivity Commission could be accurately described that way. Whether better or worse, they were demonstrably different. Still, even in early 2013 , half of voters claimed to think that, if they won the next election, Tony Abbott and the Liberals would try to bring back industrial laws similar to WorkChoices (Woods 2013). That said, as more people entered the voting population without a vivid memory of the 2005-07 campaign, recollection of WorkChoices faded. No small part of O'Connor's challenge became to find a way of communicating the problems with the government's plans in a way that was both resonant and persuasive.

\section{Election issues: Union misbehaviour}

The Heydon Commission issued an interim report in December 2014 and a final report in December 2015 (Royal Commission into Trade Union Governance and Corruption 2014, 2015). The first substantive thing the reader encountered in volume two of the final report was an unattributed poem—about blackmail. Written before World War I, it was seen as an argument against peace with future enemies. By placing it here, Commissioner Heydon consciously likened unions, particularly the Maritime Union of Australia, to Viking raiders, saying that if you give in to union demands once, they will keep coming back until you finally defeat them. It was hardly an unbiased view of trade unions in twentyfirst-century Australia. Nor was it the only hint of bias in the report or its behaviour (Ackland 2015; Conroy 2015; Crowe 2015; Grattan 2015; Karp 2016; Long 2015). Such bias was hardly surprising. Although royal commissions 'attract public confidence as being impartial, nonpolitical and independent' (Ransley 2015), a royal commission is not 
a court, it is an arm of the executive government, or what Heydon called an 'administrative inquiry' (Long 2015; Royal Commission into Trade Union Governance and Corruption 2015). A royal commission report is like a huge, and very expensive, consultancy report, in that both provide 'third-party endorsement' of a policy for which the policymaker requires 'distancing' (Peetz 2017).

Seeking the return of the ABCC was the government's immediate response to the Heydon recommendations. The policy link, however, was not clear. The key issues to be dealt with as a result of the trade union royal commission were about proper union governance. Whatever the merits of the Heydon findings, the ABCC legislation did not principally address the issue of union governance. The ABCC's original rationale and justification was to improve productivity (Econtech 2007). That rationale was subsequently discredited, when it was found the original claims ( $\$ 3$ billion in productivity gains and rising) were based on spreadsheet errors (Allan, Dungan and Peetz 2010). Yet that rationale was still being used almost a decade later (AAP 2016a).

Legislation re-establishing the ABCC was twice rejected by the Senate. The second time it was introduced, the Heydon Commission report was the rationale mostly emphasised by the government, though union corruption was not an argument used in the earlier second reading speeches. Likewise, the government reintroduced its Registered Organisations Bill, establishing a new body separate from the FWC with responsibility for oversight of union governance issues and imposing obligations on paid and unpaid union office holders and delegates similar to those applying to company directors. After both these bills were rejected for a second time, Turnbull used these as the basis for the double-dissolution election. So industrial relations were a central issue at the beginning of the election campaign, and portrayed as an issue of union corruption.

Opinion polls suggested that the ABCC legislation had more support than it had opposition, but attracted little interest overall. In four Essential Research polls in 2016, support was in the range 32-36 per cent, opposition 16-18 per cent, neither 23-28 per cent and 'don't know' 22-27 per cent (Essential Research 2016c). While 35 per cent thought it was important, 40 per cent thought it was 'not important'. There was much higher support (around 60 per cent, compared to 13 per cent opposition) for Labor's policy of a royal commission into the banking and financial services industry (Essential Research 2016b). If the ABCC Bill 
was intended to capitalise on the unpopularity of unions, it was of limited value. Public opinion of unions had improved steadily from 1979, when 82 per cent of voters had thought unions had too much power. By 2016, this number was only 47 per cent, well down even on the 69 per cent in 1990, though up from 37 per cent in YRAW's 2007 election. More voters (74 per cent in 2013) thought big business had too much power. The proportion of voters thinking there should be stricter laws on unions had fallen from 68 per cent in 1990 to 42 per cent in 2007, but rose to 55 per cent by 2016 (Cameron and McAllister 2016). While polls had long suggested voters had little trust in union leaders, similar to MPs (Roy Morgan Research 2014), it did not follow that they gave priority to eviscerating unions. A 2015 Essential Research survey had shown that 43 per cent of voters considered that overall workers would be better off 'if unions in Australia were stronger', while only 26 per cent thought they would be worse off, figures similar to 2014 (Essential Research 2015a). In another question, 62 per cent considered that unions were important 'for Australian working people today', and just 28 per cent said they were 'not important' (Essential Research 2015b).

\section{Election issues: Penalty rates}

If the government wanted to make union misbehaviour the focus of industrial relations debate, the ALP and unions themselves wanted penalty rates (premiums for working unsociable hours, mainly nights and weekends) to play that role. Coalition members had often railed against penalty rates, and recommendations by the Productivity Commission to cut penalty rates attracted more attention than any other aspect of its report, though some parts proposed more radical changes (Peetz 2016a). When the government commissioned the report, it anticipated it could promise major changes to employment relations at the 2016 election. The Productivity Commission would provide critical third-party endorsement for radical change. The poor showing in opinion polls changed that, but such a change in political circumstances was hard to accommodate. It was not possible to simply suppress the Productivity Commission report. Nor did the government want to argue against cutting penalty rates. Instead, it passed responsibility to the FWC, which was holding its four-yearly review of modern awards, with a special focus on penalty rates in the retail 
and hospitality industries. It was in these industries that the Productivity Commission focused its recommendations for a cut in Sunday penalty rates, consistent with employer arguments.

The salience of penalty rates as an issue was blunted a little by the Labor Party's behaviour. It made a submission to the FWC case, arguing against cuts to penalty rates, but probably mainly to embarrass the government by consolidating the many instances of Coalition support for cutting penalty rates (Australian Labor Party (ALP) 2016). However, Labor hesitated to commit to legislative action. This is partly because it did not want to appear to be undermining the 'independent umpire', as legislation would do, though Labor's own Fair Work Act created a set of legislative obligations, the National Employment Standards, on matters that previously had been the sole prerogative of the FWC (AAP 2016b). More valid would be concern about how legislation could be worded. Different awards set different penalty rates. A single legislated formula for penalty rates would leave some workers better off and some worse off. Alternatively, legislation could entrench existing penalty rates, but could not have been passed before the commission brought down its decision in the retail and hospitality case. It might further highlight Sunday penalty rates in the objects of the Act (as part of the current mention of weekend rates), but that would still be no guarantee current levels would be maintained or affect the FWC case. Labor committed to intervening in the case after the election, to support penalty rates, following a precedent of at least symbolic value set by the Whitlam government (Shorten 2016). However, its support was seen as less full-blooded than that of the Greens, who vaguely promised a legislative fix.

Public opinion was strongly with the idea of penalty rates. Three Essential surveys between 2013 and 2015 asked, 'Do you think people who are required to work outside of normal hours - like night shifts, weekends or public holidays - should receive a higher hourly rate of pay?' In each, 81 per cent said 'yes', and 12 or 13 per cent said 'no' (Essential Research 2015c). In a later survey, 32 per cent approved, but 54 per cent disapproved, specifically of the Productivity Commission recommendation to cut Sunday penalty rates in retail and hospitality (Essential Research 2016a). The Australian Council of Trade Unions (ACTU) mobilised a campaign on this and other issues, discussed below, with penalty rates forming a motivating rallying cry for union members. We turn to this next. 


\section{The union campaign}

The union campaign was focused on a limited number of seats and with messages targeted to issues that appeared salient in those electorates. Unlike in 2007, when WorkChoices was the target, the emphasis was not on a single industrial relations issue. While penalty rates featured prominently, other issues more connected to the social wage were also heavily used-in some seats more significantly than penalty rates. It was not the first time since 2007 that unions had organised campaigns for the federal election; indeed, in both 2010 and 2013 the unions had also campaigned in the federal election, looking to build on the success of 2007. In both years, a key message had been to warn voters of the dangers of a return to WorkChoices, but the messages had been blunted by the Coalition's insistence that it had no such plans, and that WorkChoices was 'dead, buried and cremated'. In 2013, union members' enthusiasm for campaigning would have been undermined by the near certainty of a Labor defeat. In 2016, however, Labor was competitive in the polls, penalty rates had emerged as a potential issue around which workers could be mobilised, and a range of social wage cutbacks in the 2014 Budget gave unions a much broader platform from which they could campaign. Resources allocated by the ACTU to the campaign were increasedby raising the campaign levy on unions above its 2007 level (Colman 2016) — and a quite sophisticated campaign strategy was drawn up.

The union campaign was coordinated by the ACTU, with 22 seats targeted for 'full' campaign capacity and another 12 receiving lesser attention (comprising eight with a secondary campaign effort and four with relatively low campaigning). In each of those 22 seats with 'full' campaigning, an organiser was located for 12 months before the election, cross-union activists were encouraged and a coordinated work plan was drawn up. Campaigning involved protests, door knocks, phone calls (some even from 'call centres' in activists' homes) and other oneon-one conversations, for which activists received training. The issues focused upon were centred on the 'build a better future' theme decided upon at the ACTU Congress in 2014, and included rights at work and jobs, Medicare and health, education (the 'Gonski' reforms for school education and the future of higher education), secure retirement and 'a fair go for all' (based around the idea of everyone paying their fair share of tax). A minimum of three high-visibility weekly activities were planned for each seat (for example, in Brisbane a choral parody of the 
Twelve Days of Christmas about items Malcolm Turnbull 'took from me'), but the vehicles for activities depended on the character of the electorates (for example, in seats with high public transport usage, transport hubs were targeted, while other locations were the focus in seats with less public transport use). Issues were tailored for the electorate based on polling and modelling, and progressed serially, rather than simultaneously. Alongside this local targeting were national campaigning or events at various times, also focused on particular issues such as penalty rates or health. Separately, the Australian Education Union ran a campaign specifically on the Gonski reforms, targeting 12 marginal seats with organisers and coordinated activity, but alongside and with the support of the ACTU organisers and union activists.

In those seats with secondary or partial campaigns, organisers were typically shared or operated for a shorter period, or there were phone calls, but no other activity. In some marginal seats, no union resources were deployed at all. In total, over the last three months of the campaign, some 47,000 'conversations' with union members were had in 27 targeted electorates (McManus 2016). That represented around 3 per cent of all union members in Australia, probably around one fifth of union members in many of those electorates.

There were some interesting contrasts with the 2007 YRAW campaign (Muir and Peetz 2010), aside from the differences in messaging mentioned above. The YRAW campaign went for a longer period-over two years, after the Howard government's intentions became apparent, compared to 12 months for the 2016 campaign. However, there was tighter organisational control by the ACTU in 2016, whereas in YRAW participating unions had more autonomy and less accountability for their actions. Changes in technology, as well as in organisational capacity, facilitated both the large number of calls in a short period in 2016 and the more centralised monitoring and control in the later period. That said, some affiliates still ran their own campaigns, under the broad agenda, particularly unions representing workers in the retail and hospitality industries targeted by employer campaigns on penalty rates. Around 11 electorates, therefore, were the subject of 'blitzes' (intense campaigns by individual unions) on penalty rates. Resources were sometimes withdrawn from what looked like unwinnable seats and directed into vulnerable ones as circumstances warranted. 
After the election, the ACTU reviewed the effectiveness of its campaign through a ReachTEL survey of 1,800 voters (split evenly between 'persuadables', 'committeds' and a random control group), analysis of electorate-level swings (conducted by Shaun Wilson of Macquarie University) and interviews and discussions with many participants. Through regression analysis ( $\mathrm{n}=150$ seats), Wilson estimated the union campaign added 2.8 percentage points to the swing to Labor in 22 seats where it was targeted (after controlling for State, some demographics and several political characteristics of seats). That evaluation also showed the effectiveness of 'one-on-one' conversations with 'persuadable' union members. Amongst union members at least, these conversations appeared more influential than political party campaigning, whether via mass media, social media or direct contact.

To assess the impact of the ACTU campaign separately, I undertook polling booth-level analysis, using data obtained principally through psephologist William Bowe and multiple regression techniques. Bowe had previously published a regression analysis of the determinants of swing in the 2016 election (Bowe 2016), and I largely followed his model, but with some additional explanatory variables and using unweighted rather than weighted ordinary least squares techniques. There were 6,677 observations corresponding to polling booths in the 136 electorates that ended in a two-party preferred contest between the ALP and the Coalition. The regression (shown in Table 23.1) had controls for States, urban versus rural areas, age, mean family income, education and allowed for 'sophomore' and 'retiring member' effects arising from new members and the loss of sitting members. Equation 1 also had a separate dummy variable to cover the two extraordinary electorates of Macquarie and Macarthur, in which very large swings were registered, and a control for the effect of the GetUp! campaign (which was concentrated in a much smaller number of seats-Bass, Dickson, Dawson and New England). The minimum estimated effect of the ACTU campaign in the 22 'full campaign' seats was that it boosted the ALP two-party preferred vote by 1.7 percentage points. The effect of the GetUp! campaign was, however, likely to be grossly exaggerated by this equation (it failed miserably in New England, not included in this dataset), and part of the unusual swing in Macarthur and Macquarie may have reflected the union campaign there (such as their Medicare campaigns), though there were likely to be local factors at work regardless of the union campaign (such as candidate quality and airport issues). Excluding those variables brings the estimated swing due to the union campaign to 2.0 percentage points. This range for the likely 
effect of the union campaign (1.7 to 2.0 percentage points) is lower than that which Wilson estimates (above), but nonetheless it is significant both statistically and politically. A swing effect in that range would have made the difference between the ALP winning and losing in Herbert, Hindmarsh, Cowan, Longman and Lindsay, and accounted for a majority of the margin in Macquarie, Braddon and Eden-Monaro. This swing range is also comparable to the range of estimates of the YRAW campaign in 2007, in which the swing against the government was estimated to be 1.3 to 2 percentage points higher in electorates where local YRAW campaigns had been run (Spies-Butcher and Wilson 2008). The critical difference between the two campaigns is that in 2007 the Coalition government was defeated; in 2016, it was not. In that important sense, YRAW was the more successful campaign.

The equation also shows that the swing to Labor was higher in booths in census districts with higher proportions of less educated voters, households with mortgages, lower income households and younger voters (albeit weakly significantly). State and capital city effects were also controlled for, as was the 'sophomore' effect.

Table 23.1. Regression equation predicting two-party preferred swing to the Coalition, 2016 election

\begin{tabular}{|l|r|}
\hline Equation no: & 1 \\
\hline (Constant) & -0.069 \\
\hline Age & $(-15.487)$ \\
\cline { 2 - 2 } & 0.0000 \\
\hline Median weekly family income & $(1.949)$ \\
\hline Speak English at home & 0.000004951 \\
\cline { 2 - 2 } & $(2.657)$ \\
\hline Completed high school (percentage of adults) & -0.006 \\
\cline { 2 - 2 } & $(-1.235)$ \\
\hline Mortgaged dwellings & 0.062 \\
\hline NSW regional & $(10.405)$ \\
\cline { 2 - 2 } & -0.041 \\
\hline Melbourne & $(-7.542)$ \\
\cline { 2 - 3 } & 0.017 \\
\cline { 2 - 3 } & $(5.726)$ \\
\hline
\end{tabular}




\begin{tabular}{|c|c|}
\hline Equation no: & 1 \\
\hline \multirow[t]{2}{*}{ VIC regional } & 0.034 \\
\hline & (9.916) \\
\hline \multirow[t]{2}{*}{ Brisbane } & 0.017 \\
\hline & $(5.522)$ \\
\hline \multirow[t]{2}{*}{ QLD regional } & 0.023 \\
\hline & (7.401) \\
\hline \multirow[t]{2}{*}{ Perth } & 0.003 \\
\hline & $(0.787)$ \\
\hline \multirow[t]{2}{*}{ WA regional } & 0.021 \\
\hline & $(5.114)$ \\
\hline \multirow[t]{2}{*}{ Adelaide } & 0.002 \\
\hline & $(0.608)$ \\
\hline \multirow[t]{2}{*}{ SA regional } & 0.013 \\
\hline & $(1.065)$ \\
\hline \multirow[t]{2}{*}{ TAS } & -0.007 \\
\hline & $(-1.601)$ \\
\hline \multirow[t]{2}{*}{ ACT } & 0.018 \\
\hline & (2.982) \\
\hline \multirow[t]{2}{*}{ NT } & -0.022 \\
\hline & $(-2.814)$ \\
\hline \multirow[t]{2}{*}{ Sophomore (Liberal gain in 2013) } & 0.008 \\
\hline & (6.449) \\
\hline \multirow[t]{2}{*}{ ALP loss } & 0.019 \\
\hline & $(6.834)$ \\
\hline \multirow[t]{2}{*}{ ACTU targeted seat [22] } & -0.017 \\
\hline & $(-7.414)$ \\
\hline \multirow[t]{2}{*}{ GetUp! targeted seat [4] } & -0.033 \\
\hline & $(-6.489)$ \\
\hline \multirow[t]{2}{*}{ Macarthur or Macquarie } & -0.019 \\
\hline & $(-3.02)$ \\
\hline $\mathrm{N}$ & 6,677 \\
\hline F significance & 0.000 \\
\hline$r^{2}$ & 0.10 \\
\hline
\end{tabular}

Note. Default category is Sydney, not a sophomore, not an ALP loss, not a targeted seat

Sources. Compiled by author from: data on swings from Australian Electoral Commission; data on demographic characteristics of collector districts from Australian Bureau of Statistics 2011 census (both of the above provided to the author by William Bowe); data on targeting by ACTU from McManus (2016). Regressions undertaken by the author using SPSS22. 
For unions, the campaign was a modest electoral success. It also built up skills amongst those who participated. In a survey of 76 national and State union secretaries, conducted as part of the ACTU's post-election review, 81 per cent said their members learnt new skills, while 76 per cent of 246 activists involved in the campaign, and who were subsequently surveyed, also said they had learnt new skills. What was not clear was how much these skills translated into union organising capacity. One former ACTU official claimed unions focused on 'electoral politics because it's easier than talking about and doing real organising, and certainly easier than beginning fundamentally to transform unionism', and added, 'the election hasn't, and couldn't, change the fundamental position of unions. As institutions, unions are in a state of profound crisis' (Lyons 2016). The debates about the role of unions in electoral politics is too big for this chapter, but a strong union effect in an election campaign is not the same as a strong effect from an election campaign upon union power, even though the laws any government brings in clearly can have a major effect on union power, and elections determine who makes those laws (Freeman and Pelletier 1990; Rose and Chaison 1985). Some other issues concerning unions-such as whether they would have benefited from a more proactive, visible stance on union corruption-are also beyond the scope of this chapter (Peetz 2016b).

\section{Election issues: The Road Safety Remuneration Tribunal and the Victorian Country Fire Authority}

Leading up to the election, the government focused on two issues that provided an opportunity to attack unions and Labor. The first was the Road Safety Remuneration Tribunal (RSRT). It had been established by Labor to deal with the problem that low pay for owner-drivers contributed to the industry having amongst the longest working hours and the most deaths - especially bystander deaths — of any industry (Australian Bureau of Statistics (ABS) 2014; Quinlan 2016; Safe Work Australia 2015). The road transport industry was based on 'hierarchical contracting'-a variant of the model used in franchising - a model in which top firms avoid accountability, but retain control and extract profit, making collective organisation hard, transferring risk to workers (and contractors) at the end of the supply chain and concentrating profits at the core. Using the 
corporations power in the Constitution, and following examples in the apparel industry in Australia and internationally (Kaine and Brigden 2015; Reinecke and Donaghey 2015), the RSRT set minimum pay rates for distances and for hours of owner-drivers. It met resistance from the top of the supply chain (where profits were threatened) and some contractors (who faced a loss of income from empty 'backloads'). Three months before the election, the government demonised the RSRT (Greenwood and Cash 2016), greeted and addressed protesters at a 'convoy to Canberra' and then abolished it (Retail Council 2016). Although Labor opposed its abolition, the issue did not subsequently feature prominently in the election campaign itself.

The same could not be said about the Victorian Country Fire Authority (CFA), which was magnified as an issue in the last weeks of the campaign. The CFA employs 800 firefighters and coordinates 60,000 volunteer firefighters. In 32 of its 1,186 fire stations, paid and volunteer staff worked alongside each other (that is, they were 'integrated' stations). The CFA had been in stalled negotiations with the United Firefighters Union, with which it had 'toxic' relations, for a new enterprise bargaining agreement (EBA). A FWC recommendation had been to limit the EBA's application to employees and integrated stations, not volunteers, and prioritise the discretionary powers of incident controllers when public safety was concerned (Teicher 2016). The CFA board had secretly commissioned a report recommending it hire firefighters on individual or non-union contracts and 'erode public confidence in the union agenda' (Toscano and Willingham 2016). The Victorian Labor government sought to end the dispute by accepting the FWC recommendations, but the minister resigned, and shortly thereafter the Victorian government sacked the CFA board. Federal government ministers, including Veterans Affairs Minister Dan Tehan from rural Victoria, saw an opportunity to use this to attack unions and a State Labor government (Patrick 2016). Two weeks before the election, Turnbull promised to overturn the EBA and legislate to prevent any agreement affecting volunteer firefighting (Keen 2016).

The issue had no salience outside Victoria, but was seen as influencing the vote in that State. The swing to Labor in Victoria (VIC) was the lowest of all States, but that State had not performed strongly for Labor in the AprilMay 2016 Newspoll either. Analysis by Matt Cowgill revealed that there was a small, weakly positive correlation between the two-party preferred swing to Labor and a booth's distance from the nearest integrated station, 
again suggesting no CFA effect (Cowgill 2016). That said, Labor lost the seat of Chisholm and failed to pick up La Trobe or Dunkley, though they had not been strong prospects anyway. The most plausible assessment is that the CFA dispute cost Labor one seat it would otherwise have held.

\section{And non-issues}

Just as noteworthy as the issues that made it to the electoral agenda are some that did not. One obvious example was of worker underpayment. A series of media investigations uncovered a pattern of wage theft at a major retail franchise, 7-Eleven. In a majority of franchises, staff were paid below the award, with one franchise agent saying, 'nobody pays their staff full wage, man' (Ferguson and Toft 2015), and the estimated cost reportedly totalled $\$ 100$ million (Ferguson and Danckert 2016). Despite the franchise model lending itself to this exploitation-it is designed to transfer risk from the corporate franchisor to the franchisee (Kellner et al. 2016) - issues of systemic weakness did not make it to the political agenda. Similarly, there were several exposés of underpayment and other exploitation of migrant workers (e.g. Schneiders and Millar 2015; Vines 2015). Underpayments are so common among restaurateurs that when one was caught, the excuse used would be 'everyone is doing it' (Marin-Guzman 2016). Government policies aimed at reducing union power would potentially worsen this evasion. The government response to revelations of further 7-Eleven breaches during the election campaign was to promise to increase the powers of the Fair Work Ombudsman (FWO) to investigate corporations at the top of franchise chains and increase powers for the FWO to compel answers to questions (Cash 2016). There was no employer outrage at these encroachments on employer prerogative, suggesting the likely cost would be small, or that those increased powers could also be used against workers - the FWO had previously launched investigations into journalists who walked off the job after Fairfax announced more redundancies (Toscano 2016). However, using such powers in that way after the election, without obtaining a mandate beforehand, would be a risky strategy and so the attempt to embody them in the subsequent legislation was rejected by the Senate (Marin-Guzman 2017; Patty 2017).

The government was more reticent about its response to the Productivity Commission report. Almost nothing was revealed, avoiding the danger of controversy in return for removing any prospect of a mandate for major 
IR changes in the 2016-19 term. As it was, the thin majority in the House of Representatives, and the lack of majority in the Senate almost guaranteed no rerun of the WorkChoices experience in the term to come.

\section{Conclusion}

IR was in a sense the sleeping giant of the election. Both sides attempted to waken it on their terms, but keep it asleep on the other side's terms. Neither side engaged strongly with the other's agenda, and this made IR less visible in the media. As to its effects, perhaps the question is: in an election in which penalty rates featured, albeit intermittently, who paid that penalty? The answer is not clear, but overall IR was probably a net positive for the ALP, especially compared to Coalition expectations. Labor probably lost a seat in Victoria as a result of it, but picked up at least five, possibly more, due to the union campaign. That made the difference between a tenuous and a comfortable margin for the government.

The government's attempts to develop 2016 as an election about union corruption and misbehaviour were not very effective. In that sense, 2016 was more like 1983, or 2007, than 1998, but not really like any other year-union misbehaviour was a stronger issue in 2016 than in the wagefreeze election of 1983, and industrial relations, as an issue, was less powerful in switching government than in 2007.

Legislative efforts to weaken unions can be expected over the coming three years. Yet one of the enduring problems for the government is now that its unwillingness to reveal a program of IR reform in the lead up to the 2016 election leaves it without a real mandate for radical reform in the forthcoming term. While this may run counter to the deep instincts of Coalition politicians, the slender majority in the House of Representatives and lack of a majority in the Senate would militate against any radical program anyway. It would be a courageous Coalition that sought to bring in radical changes in those circumstances.

\section{References}

Abbott, Tony. 2002. Explanatory Memorandum, Workplace Relations Amendment (Simplifying Agreement-Making) Bill 2002. Canberra: House of Representatives. 
—. 2009. Hansard (Commonwealth Parliamentary Debates). House of Representatives. 13 August, 7794.

Abetz, Eric. 2014. 'Industrial relations after the thirty years war - address to the Sydney Institute'. Speech: 28 January. Available at: ministers. employment.gov.au/abetz/industrial-relations-after-thirty-years-waraddress-sydney-institute

Ackland, Richard. 2015. 'He’s staying! No-bias Dyson Heydon slices his reasons deli-thin'. Guardian, 31 August. Available at: www. theguardian.com/commentisfree/2015/aug/31/hes-staying-no-biasdyson-heydon-slices-his-reasons-deli-thin

Allan, Cameron, Andrew Dungan and David Peetz. 2010. "Anomalies", damned "anomalies" and statistics: Construction industry productivity in Australia'. Journal of Industrial Relations 52(1): 61-79.

Australian. 2010a. 'Avoiding a wages breakout'. Weekend Australian, 26 November. Available at: www.theaustralian.com.au/opinion/ editorials/avoiding-a-wages-breakout/story-e6frg71x-1225961115411

— 2010b. 'Memo world: Wake up and smell the debt'. Weekend Australian, 6 February. Available at: www.theaustralian.com.au/ opinion/editorials/memo-world-wake-up-and-smell-the-debt/storye6frg71x-1225827270918

—. 2011a. 'Gillard's intervention risks a wages breakout'. Weekend Australian, 12 November. Available at: www.theaustralian.com.au/ opinion/editorials/gillards-intervention-risks-a-wages-breakout/storye6frg71x-1226193105544

- 2011b. 'IR rigidity eroding confidence'. Weekend Australian, 2 February. Available at: www.theaustralian.com.au/opinion/editorials/ ir-rigidity-eroding-confidence/story-e6frg71x-1225998321085

. 2011c. 'Unions threaten a wages war'. Weekend Australian, 22 February. Available at: www.theaustralian.com.au/opinion/editorials/ unions-threaten-a-wages-war/story-e6frg71x-1226009670111 
Australian Associated Press (AAP). 2011. 'Liberal backbencher John Alexander "has revealed coalition will bring back Work Choices". news. com.au, 15 August. Available at: www.news.com.au/national/liberalbackbencher-john-alexander-has-revealed-coalition-will-bring-backwork-choices/news-story/7ee595b9987f9d6655a896bc49e28ead

_- 2015. 'Show courage on penalty rates: Lib senator'. SBS News, 23 December. Available at: www.sbs.com.au/news/show-courage-onpenalty-rates-lib-senator

—_. 2016a. 'Australia can't afford no ABCC: Morrison'. SBS News, 17 February. Available at: www.sbs.com.au/news/australia-can-t-affordno-abcc-morrison

_ _ 2016b. 'Umpire will protect penalty rates: Shorten'. SBS News, 17 May. Available at: www.sbs.com.au/news/article/2016/05/17/ umpire-will-protect-penalty-rates-shorten

Australian Broadcasting Corporation (ABC). 2013. 'Liberal candidate says workplace policy comes after election, not before'. ABC News, 29 August. Available at: www.abc.net.au/news/2013-08-29/workchoicessudmalis/4920352

—_. 2014. 'Promise tracker: The Abbott Government's broken election promises jump from 8 to 12'. ABC News, 7 November. Available at: www.abc.net.au/news/2014-11-07/abbott-government-brokenpromises-jumps-to-12/5870784

Australian Bureau of Statistics (ABS). 2014. 6306.0_Employee Earnings and Hours, Australia. Canberra: Australian Government Printing Service. Available at: www.abs.gov.au/AUSSTATS/abs@.nsf/Lookup/ 6306.0Main+Features1May\%202014?OpenDocument

Australian Labor Party (ALP). 2016. 'Federal Opposition submission to the Fair Work Commission's review of modern awards - penalty rates'. 21 March. Available at: d3n8a8pro7vhmx.cloudfront.net/australianl aborparty/pages/4941/attachments/original/1458607155/Federal_ Opposition_-_Submission_to_FWC_-_Penalty_Rates_Review.pdf? 1458607155

Bachelard, Michael. 2007. 'Workplace ad pulled over bad boss claim'. Age, 7 August, p. 1. 
Bourke, Latika. 2015. 'Malcolm Turnbull: Lower penalty rates inevitable with "seven day economy"'. Sydney Morning Herald, 6 October. Available at: www.smh.com.au/federal-politics/political-news/malcolm-turnbulllower-penalty-rates-inevitable-with-seven-day-economy-20151005gk1yr5.html

Bowe, William. 2015. 'BludgerTrack: 52.5.-47.5 to Labor'. Poll Bludger Blog, 23 January. Available at: blogs.crikey.com.au/pollbludger/ 2014/01/23/bludgertrack-52-5-47-5-to-labor/

—. 2016. 'Election plus two weeks'. Poll Bludger Blog, 17 July. Available at: blogs.crikey.com.au/pollbludger/2016/07/17/electionplus-two-weeks/

Brent, Peter. 2010. 'Remember the sophomore surge'. Mumble Blog, 11 August. Originally available at: blogs.theaustralian.news.com.au/ mumble/index.php/theaustralian/comments/todays_cumulative_ newspoll/ (accessed 25 March 2016, site discontinued).

— 2014. 'Surging with the sophomores'. Inside Story, 19 September. Available at: insidestory.org.au/surging-with-the-sophomores

Cameron, Sarah and Ian McAllister. 2016. 'Trends in Australian political opinion: Results from the Australian Election Study 19872016. Canberra: School of Politics and International Relations, The Australian National University.

Cash, Michaelia. 2016. 'Protecting vulnerable workers in Australia', 19 May. Liberal Party of Australia.

Colman, Elizabeth. 2016. 'Federal election 2016: ACTU opens war chest for marginal seats blitz. The Australian, 6 May, p. 7.

Conroy, Stephen. 2015. 'Senator Stephen Conroy exposes Heydon's full links to the Liberal Party'. Independent Australia, 21 August. Available at: independentaustralia.net/politics/politics-display/senator-stephenconroy-exposes-heydons-full-links-to-the-liberal-party,8079

Coorey, Phillip. 2005. 'Howard's IR fast-track'. Advertiser, 11 November, p. 9.

Cowgill, Matt. 2016. 'I re-did my graphs comparing 2pp swings (Tweet)'. 10 July. 
Crowe, David. 2007. 'WorkChoices does the job for Labor'. Australian Financial Review, 26 November, p. 5.

. 2015. 'TURC clears Shorten, does itself no favours'. Weekend Australian, 7 November. Available at: www.theaustralian.com.au/ national-affairs/industrial-relations/turc-clears-shorten-does-itself-nofavours/news-story/c5824a23aecbdf56309bb39b33f2b8a8

Curtis, Lyndal. 2010. 'Abbott sends mixed WorkChoices messages'. $A B C$ News, 19 July. Available at: www.abc.net.au/news/2010-07-19/ abbott-sends-mixed-workchoices-messages/911064

Doran, Matthew and Stephen Dziedzic. 2016. 'Federal Government agrees to show trade union royal commission findings to Labor, Greens'. ABC News, 1 February. Available at: www.abc.net.au/news/ 2016-02-01/government-agrees-to-show-turc-findings-to-labor,greens/7130520

Econtech. 2007. 'Economic analysis of building and construction industry productivity'. Report Prepared for the Office of the Australian Building and Construction Commissioner, 16 July. Canberra: Econtech Pty Ltd.

Essential Research. 2015a. 'Better or worse off with stronger unions'. Essential Report, 27 October. Available at: www.essentialvision.com. au/better-or-worse-off-with-stronger-unions- 4

—_. 2015b. 'Importance of unions'. Essential Report, 20 May. Available at: www.essentialvision.com.au/importance-of-unions-3

—_. 2015c. 'Penalty rates'. Essential Report, 11 August. Available at: www.essentialvision.com.au/tag/penalty-rates

—_. 2016a. 'Penalty rates'. Essential Report, 23 February. Available at: www.essentialvision.com.au/wp-content/uploads/2016/02/essential_ report_160223.pdf

—_. 2016b. 'Royal Commission into banking'. Essential Report, 16 August. Available at: www.essentialvision.com.au/royal-commissioninto-banking-2

__. 2016c. 'Support for re-establishing the Australian Building and Construction Commission'. Essential Report, 25 October. Available at: www.essentialvision.com.au/support-for-re-establishing-the-australianbuilding-and-construction-commission 
Ferguson, Adele and Sarah Danckert. 2016. '7-Eleven: Wage compensation bill may top $\$ 100$ million'. Sydney Morning Herald, 9 April. Available at: www.smh.com.au/business/workplace-relations/ 7eleven-compensation-wage-bill-may-top-100-million-20160408goleo $7 . h$ tml

Ferguson, Adele and Klaus Toft (Writers). 2015. '7-Eleven: The price of Convenience'. 4 Corners, 30 August. Available at: www.abc.net. au/4corners/stories/2015/08/30/4301164.htm

Fisher, Leo D'Angelo. 2014. 'One-Term Tony simply isn't up to the job of PM: the man who should have been Sports Minister' Leo D'Angelo Fisher, 8 December. (Original title: 'A “ragged” year for Tony Abbott, but does the PM have what it takes to save his hapless government or will it be more of the same in 2015?'). Available at: leodangelofisher. com/2014/05/15/if-things-dont-pan-out-as-pm-lycra-loving-tonyabbott-would-make-an-excellent-sports-minister/

Freeman, Richard B. and Jeffrey Pelletier. 1990. 'The impact of industrial relations legislation on union density in the UK and Ireland'. British Journal of Industrial Relations 28(2): 141-64.

Gawenda, Michael. 2014. 'The dubious virtues of Abbott's revolution'. Weekend Australian (Business Spectator), 5 February. Available at: www.theaustralian.com.au/business/business-spectator/the-dubiousvirtues-of-abbotts-revolution-/news-story/5741 eb0d22bafbbdac5feb7 $802 \mathrm{e} 3990$

Grattan, Michelle. 2015. 'Heydon's email trail for Barwick dinner made its Liberal connections clear from the start'. The Conversation, 17 August. Available at: theconversation.com/heydons-email-trail-for-barwickdinner-made-its-liberal-connections-clear-from-the-start-46211

Greenwood, Ross and Michaelia Cash (Writers). 2016. 'Convoy to Canberra'. Sydney: 2GB.

Hartcher, Peter. 2014. 'Tony Abbott is the problem with the federal government: Poll'. Sydney Morning Herald, 8 December. Available at: www.smh.com.au/federal-politics/political-opinion/tony-abbott-isthe-problem-with-the-federal-government-poll-20141207-12247a 
Hudson, Phillip. 2005. 'All power to Howard'. Age, 7 August. Available at: www.theage.com.au/news/national/all-power-to-howard/2005/08/ 06/1123125938970.html

Janda, Michael. 2016. 'Wage growth hits record low of 1.9pc: ABS'. $A B C$ News, 16 November. Available at: www.abc.net.au/news/201611-16/wage-price-index-september-quarter-abs/8029610

Kaine, Sarah and Cathy Brigden. 2015. 'Union responses to regulatory change: Strategies of protective layering'. Economic and Labour Relations Review 26: 614-30. doi.org/10.1177/1035304615615275

Karp, Paul. 2016. 'Return to sender: Unions royal commission apologises over privacy blunder'. Guardian, 6 April. Available at: www.theguardian.com/australia-news/2016/apr/06/return-to-senderunions-royal-commission-apologises-over-privacy-blunder

Keen, Lucille. 2016. 'Turnbull government promises to overturn CFA deal if re-elected'. Australian Financial Review, 15 June. Available at: www.afr.com/news/policy/industrial-relations/turnbull-governmentpromises-to-overturn-cfa-deal-if-reelected-20160615-gpjh48

Kellner, Ashlea, David Peetz, Keith Townsend and Adrian Wilkinson. 2016. "We are very focused on the muffins": Regulation of and compliance with industrial relations in franchises'. Journal of Industrial Relations 58(1): 25-45. doi.org/10.1177/0022185615598186

Kenny, Mark and Clay Lucas. 2013. 'Liberals ire as Abetz goes "freelancing". Sydney Morning Herald, 23 August, p. 14.

Koutsoukis, Jason, Renee Switzer and Deborah Gough. 2007. 'Truth in advertising: What you see is what you get'. Sunday Age, 23 September, p. 1.

Liberal Party of Australia and National Party. 2013. 'The Coalition's policy to improve the fair work laws'. Parliament of Australia May. Available at: parlinfo.aph.gov.au/parlInfo/download/library/partypol/ 2429303/upload_binary/2429303.pdf;fileType=application\%2Fpdf\# search $=\% 22$ library $/$ partypol $/ 2429303 \% 22$

Long, Stephen. 2015. 'Why is no one questioning the TURC narrative?' $A B C$ News, 22 October. Available at: www.abc.net.au/news/2015-1022/long-why-is-no-one-questioning-the-turc-narrative/6868102 
Lyons, Tim. 2016. 'The Labour movement: My part in its downfall'. Meanjin Quarterly, Spring. Available at: meanjin.com.au/essays/thelabour-movement-my-part-in-its-downfall/

Maley, Paul. 2007. 'WorkChoices fear campaign to blame'. Australian, 26 November, p. 8.

Marin-Guzman, David. 2016. 'Popular restaurant chain caught in underpayments scandal'. Workplace Insight, 19 January. Available at: sites.thomsonreuters.com.au/workplace/2016/01/19/popularrestaurant-chain-caught-in-underpayments-scandal/

—. 2017. 'Vulnerable workers bill provides new powers to investigate strikes'. Australian Financial Review, 17 August. Available at: www. afr.com/news/policy/industrial-relations/vulnerable-workers-billprovides-new-powers-to-investigate-strikes-20170817-gxy9mv\#ixzz4 xapTR1RZ

Massola, James. 2014. 'Abetz says WorkChoices scare "neutralised" by Coalition'. Sydney Morning Herald, 3 September, p. 3.

McAllister, Ian and Sarah M. Cameron. 2014. 'Trends in Australian Public Opinion: Results from the Australian Election Survey 19872013'. Canberra: School of Politics and International Relations, The Australian National University.

McCrann, Terry. 2008. 'Beware a wages explosion'. Courier-Mail, 7 May. Available at: www.couriermail.com.au/news/beware-a-wagesexplosion/story-e6frergx-1111116267245

McManus, Sally. 2016. Interview with author. 9 September, Melbourne.

Morris, Sophie. 2007. 'Small swings, vital losses'. Australian Financial Review, 26 November, p. 14.

Muir, Kathie and David Peetz. 2010. 'Not dead yet: The Australian union movement and the defeat of a government'. Social Movement Studies 9(2): 215-28. doi.org/10.1080/14742831003603380

O'Brien, Kerry. 2013. 'Abbott quizzed on immigration policy'. $A B C$ News, 28 July. Available at: www.abc.net.au/news/2010-07-26/abbottquizzed-on-immigration-policy/920460 
Patrick, Aaron. 2016. 'Fighting fires: The militant union leader who cost Bill Shorten the Lodge'. Australian Financial Review, 5 August. Available at: www.afr.com/news/politics/election/fighting-fires-themilitant-union-leader-who-cost-bill-shorten-the-lodge-20160726gqelug

Patty, Anna. 2017. 'Vulnerable workers bill passed with some compromise'. Sydney Morning Herald, 5 September. Available at: www.smh.com.au/ business/workplace-relations/vulnerable-workers-bill-passed-withsome-compromise-20170904-gyaqy7.html

Peetz, David. 2002. 'Sympathy for the devil? Australian unionism and public opinion'. Australian Journal of Political Science 37(1): 57-80. doi.org/10.1080/13603100220119029

—_. 2007. 'Assessing the impact of workchoices - one year on'. Melbourne: Industrial Relations Victoria, Department of Innovation, Industry and Regional Development.

—— 2010. 'Are individualistic attitudes killing collectivism?' Transfer - European Review of Labour and Research 16(3): 383-98. doi.org/ $10.1177 / 1024258910373869$

—_. 2016a. 'The Productivity Commission and Industrial Relations reform'. Economic and Labour Relations Review 27(2): 164-80. doi.org/ $10.1177 / 1035304616649305$

—_. 2016b. 'Sorting the gems from the dung in the royal commission on union corruption'. The Conversation, 29 April. Available at: theconversation.com/sorting-the-gems-from-the-dung-in-the-royalcommission-on-union-corruption-57202

—_. 2017. 'Why establish non-representative organisations? Rethinking the role, form and target of think tanks'. In Alejandra Salas-Porras and Georgina Murray (eds), Think-tanks: Key Spaces in the Global Structure of Power. Basingstoke: Palgrave MacMillan, pp. 245-63.

Price, Jenna. 2014. 'Fair work amendment bill is a recipe for exploitation'. Brisbane Times, 1 September. Available at: www.brisbanetimes.com. $\mathrm{au} /$ comment/fair-work-amendment-bill-is-a-recipe-for-exploitation20140901-10b13y.html 
Quinlan, Michael. 2016. 'FactCheck: Do better pay rates for truck drivers improve safety?' The Conversation, 13 April. Available at: theconversation.com/factcheck-do-better-pay-rates-for-truck-driversimprove-safety-57639

Ransley, Janet. 2015. 'A rocky road for unwary royal commissioners'. Inside Story, 31 August. Available at: insidestory.org.au/a-rocky-roadfor-unwary-royal-commissioners

Reinecke, Juliane and Jimmy Donaghey. 2015. 'After Rana Plaza: Building coalitional power for labour rights between unions and (consumptionbased) social movement organisations'. Organization 22(5): 720-40. doi.org/10.1177/1350508415585028

Retail Council. 2016. 'Statement on the abolition of the RSRT', 19 April, Sydney. Originally available at: www.retailcouncil.com.au/ media-releases/statement-on-the-abolition-of-the-rsrt?A=WebApp\& $\mathrm{CCID}=12829 \&$ Page $=4 \&$ Items $=1 \quad$ (accessed 2 December 2016, site discontinued).

Roberts, Greg. 2010. 'Anti-union ad actor faces drug charges'. Sydney Morning Herald, 13 April. Available at: www.smh.com.au//breakingnews-national/antiunion-ad-actor-faces-drug-charges-20100413s5qk.html

Rose, Joseph B. and Gary N. Chaison. 1985. 'The state of the unions: United States and Canada'. Journal of Labor Research 6(1): 97-111. doi.org/10.1007/BF02685155

Roy Morgan Research. 2014. 'Roy Morgan Image of Professions Survey 2014 - Nurses still most highly regarded - followed by Doctors, Pharmacists \& High Court Judges'. Morgan Poll (Finding No. 5531), 11 April, Sydney.

Royal Commission into Trade Union Governance and Corruption. 2014. 'Interim Report'. Canberra: Department of the Prime Minister and Cabinet. Available at: www.tradeunionroyalcommission.gov.au/ reports/Pages/default.aspx

2015. 'Final Report'. Canberra: Department of the Prime Minister and Cabinet. Available at: www.tradeunionroyalcommission.gov.au/ reports/Pages/Final-Report.aspx 
Safe Work Australia. 2015. 'Notifiable fatalities - monthly report'. December.

Saulwick, Jacob, Heath Aston, Kim Arlington and Angelo Risso. 2013. 'Liberal candidates duck the spotlight, fearing the "Jaymes Diaz effect"'. Sydney Morning Herald, 28 August. Available at: www.smh. com.au/federal-politics/federal-election-2013/liberal-candidates-duckthe-spotlight-fearing-the-jaymes-diaz-effect-20130828-2sq3a.html

Schneiders, Ben and Royce Millar. 2015. “Black jobs”: Rampant exploitation of foreign workers in Australia revealed'. Sydney Morning Herald, 3 October, p. 27.

Shorten, Bill. 2016. 'Only Labor will protect penalty rates system for workers'. Labor Herald, 16 May. Originally available at: www.labor herald.com.au/people-families/only-labor-will-protect-penalty-ratessystem-for-workers/ (accessed 2 December 2016, site discontinued).

Special Broadcasting Service (SBS). 2015. 'Abbott warms to penalty rate changes'. SBS News, 23 January. Available at: www.sbs.com.au/news/ article/2015/01/23/abbott-warms-penalty-rate-changes

Spies-Butcher, Ben and Shuan Wilson. 2008. 'Election 2007: Did the union campaign succeed?' Australian Review of Public Affairs, February. Available at: www.australianreview.net/digest/2008/02/spies-butcher_ wilson.html

Sydney Morning Herald. 2014. 'Then and now: The Abbott government's broken promises'. Sydney Morning Herald, 14 May. Available at: www. smh.com.au/business/federal-budget/then-and-now-the-abbottgovernments-broken-promises-20140514-zrcfr.html

Taft, Peter. 1998. 'Does who wins matter more or less?' Public Policy Program, Discussion Paper No. 57, July. Canberra: The Australian National University.

Taylor, Lenore. 2015. 'Tony Abbott says cutting penalty rates will create jobs, but voters disagree'. Guardian, 23 January. Available at: www. theguardian.com/australia-news/2015/jan/23/coalition-faces-uphilltask-convincing-even-their-supporters-on-penalty-rates 
Teicher, Julian. 2016. 'What's the Victorian government's dispute with the CFA about? And how will it affect the election?' The Conversation, 29 June. Available at: theconversation.com/whats-the-victoriangovernments-dispute-with-the-cfa-about-and-how-will-it-affect-theelection-61631

Toscano, Nick. 2016. 'Fairfax journalists to be investigated by FWO'. Sydney Morning Herald, 4 May. Available at: www.smh.com.au/ business/workplace-relations/fairfax-journalists-to-be-investigated-byfwo-20160504-gom6ak.html

Toscano, Nick and Richard Willingham. 2016. 'Firefighter stoush: Secret report for CFA reveals anti-union ambitions'. Age, 6 September. Available at: www.theage.com.au.ezproxy1.library.usyd.edu.au/victoria/ firefighter-stoush-secret-report-for-cfa-reveals-antiunion-ambitions20160905-gr9dtc.html

Uhlmann, Chris. 2009. 'ETS bill voted down'. ABC News, 2 December. Available at: www.abc.net.au/news/2009-12-02/ets-bill-voted-down/ 2674186

Vines, Helen. 2015. 'Thousands of workers underpaid, denied entitlements by Australian employers figures show'. $A B C$ News, 23 February. Available at: www.abc.net.au/news/2015-02-22/ thousands-of-australians-underpaid-denied-entitlements/6189802

Woods, Jackie. 2013. 'WorkChoices still haunts Coalition's cred on IR'. $A B C$ News, 21 May. Available at: www.abc.net.au/news/2013-05-21/ woods-industrialrelations/4702770

\section{Legislation}

Fair Work Act 2009 (Cth).

Fair Work Amendment (Bargaining Processes) Bill 2014 (Cth). 
This text is taken from Double Disillusion: The 2016 Australian Federal Election, edited by Anika Gauja, Peter Chen, Jennifer Curtin and Juliet Pietsch, published 2018 by ANU Press, The Australian

National University, Canberra, Australia.

doi.org/10.22459/DD.04.2018.23 